\title{
Effects of zero burning waste on the quality of liquid fertilizer and vermicompost
}

\author{
Adi Jaya ${ }^{1 *}$, Bambang S. Lautt ${ }^{1}$, Emmy U. Antang ${ }^{1}$, Sosilawaty Sibot ${ }^{1}$, Salampak Dohong ${ }^{1}$, \\ Panji Surawijaya ${ }^{1}$, Salundik Dohong ${ }^{2}$ \\ (1. Faculty of Agriculture, The University of Palangka Raya, Palangka Raya 73112, Indonesia; \\ 2. Faculty of Animal Husbandry IPB University, Bogor 16680, Indonesia)
}

\begin{abstract}
Peatland is an important ecosystem in Indonesia. But in almost every dry season, drained peatlands have been subject to detrimental wildfires. As a response, the government has explicitly prohibited the burning of land since 2016 . To clear the land of crop residues and conduct zero burning practices, one alternative method is to utilize the waste biomass to support the cultivation of earthworms (vermiculture). This study examined the quality of liquid fertilizers and compost produced from vermiculture using a completely randomized factorial design, consisting of two treatment factors. The first factor was worm type, with two species used in this research named Lumbricus rubellus and Eudrilus eugeniae. The second factor was the type of feed provided to the worms, comprising no feed (control), vegetable waste, and crop residue waste resulting from zero burning land preparation. The type of feed significantly affected the $\mathrm{pH}$ value of the liquid fertilizer produced by the vermiculture but did not significantly affect the nutrient contents $(\mathrm{N}, \mathrm{P}$, and $\mathrm{K})$. The combination of the types of earthworms and types of feed significantly affected the $\mathrm{pH}$ value of the vermicompost. The combination of worm types and feed types had a significant effect on exchangeable $\mathrm{Ca}$, but not on exchangeable $\mathrm{Mg}, \mathrm{Na}$, and $\mathrm{K}$. In combination, green vegetable waste and Lumbricus rubellus produced the greatest effect on soil CEC. However, for Base Saturation, the control (no food) and Eudrilus eugeniae showed the highest value. Types of worms and types of feed had a significant effect on the exchangeable $\mathrm{Mg}$, while the other three parameters made no significant differences. Zero burning waste and Eudrilus eugeniae provide a better exchangeable $\mathrm{Ca}$ and $\mathrm{Mg}$. In contrast, no-feeding and Eudrilus eugeniae have a better effect on exchangeable Na and $\mathrm{K}$. Types of worms and types of feed did not significantly affect the weight of worm colonies, but the addition of feed increased the weight of worms with the highest weight resulting from the use of zero burning waste feed. The results showed that crop residue wastes were potentially good as a feed for earthworms.
\end{abstract}

Keywords: liquid organic fertilizer, vermicompost, Lumbricus rubellus, Eudrilus eugeniae, zero burning waste, crop residue, land preparation

DOI: $10.25165 /$ j.ijabe.20201304.4814

Citation: Jaya A, Lautt B S, Antang E U, Sibot S, Dohong S, Surawijaya P, et al. Effects of zero burning waste on the quality of liquid fertilizer and vermicompost. Int J Agric \& Biol Eng, 2020; 13(4): 159-165.

\section{Introduction}

In Indonesia, peatland ecosystems are important at the global scale as large carbon stores $^{[1]}$ and at the local scale for communities' farming activities. Since 1997, peatland and forest fires have been seen nearly every dry season, which is very detrimental to the environment, to people's health and the economy. For local people dependent on smallholder farming, fire is one of the cheaper ways of clearing and preparing their land. In addition to clearing crop debris or scrub, peat burning can also help improve the fertility of the land since the ash from fires provides a cheap

\section{Received date: 2018-12-01 Accepted date: 2020-04-12}

Biographies: Bambang S. Lautt, PhD, Professor, research interests: plant physiology, Email: blautt63@gmail.com; Emmy U. Antang, PhD Candidate, research interests: livelihood and food security, Email: emmyantang@ agb.upr.ac.id; Sosilawaty Sibot, $\mathrm{PhD}$, research interests: forest management, Email: sosilawaty@for.upr.ac.id; Salampak Dohong, PhD, Professor, research interests: soil chemistry, Email: salampak@agr.upr.ac.id; Panji Surawijaya, $\mathrm{PhD}$, research interests: agriculture mechanization, Email: surawijayapanji@ ymail.com; Salundik Dohong, $\mathrm{PhD}$, research interests: animal waste management, Email: ndikipb@yahoo.co.id.

*Corresponding author: Adi Jaya, $\mathrm{PhD}$, research interests: peatland management. Faculty of Agriculture, The University of Palangka Raya, Indonesia. Tel: +62-5363227863, Email: adijaya@agr.upr.ac.id. source of fertilizer to assist local people with their crop cultivation. Until recently, burning was a regular agricultural practice, but newly implemented legal sanctions have proscribed fire use. This ban had a negative impact on farmer livelihoods and food security; led to a decline in production since farmers were less capable to cultivate crops, and eventually impacted the availability of local food. The community economy in the peatland areas of Indonesia is classified as weak, and the restricted availability of cheap fertilizer deteriorated this problem.

One alternative to the use of fire is to utilize land preparation waste as a feedstock for earthworm cultivation, which can both be a source of protein for livestock or fish and be the organic fertilizer for crop cultivation. By applying the concept of zero waste in the agricultural system, crops can be cultivated organically by utilizing the liquid fertilizer produced from earthworm cultivation along with the vermicompost. The cultivation of land without burning can also provide a solution for land clearing and preparation as well as an important source of fertilizer for agricultural cultivation.

The use of earthworms in the decomposition of organic materials is one approach to add value to waste disposal. Earthworms can utilize wastes in the form of livestock manure and plant material as a breeding medium and also as feed ${ }^{[2]}$. The earthworms can decompose such material three to five times faster 
than microbes ${ }^{[3]}$, thus shortening the production time of compost fertilizer ${ }^{[4]}$. Red earthworms (Lumbricus rubellus), for example, can degrade lignocellulose compounds, producing worm droppings that become a food source for composting bacteria ${ }^{[5]}$. In addition, several studies have shown that the use of vermicompost as fertilizer can produce good results for plants and reduce the use of inorganic fertilizers ${ }^{[6-9]}$. This can solve the problems of quality deterioration of both soil and edible products in conventional farming systems, which was characterized by high inputs of chemical fertilizers and reductions in soil organic matter content ${ }^{[10,11]}$. As a response, the use of organic farming as nutrient inputs with organic amendments to the soil is increasing and provides an alternative agricultural practice for sustaining economically viable crop production with minimal environmental pollution $^{[12]}$. Among the various organic soil amendments, vermicompost is one option, which can play a role in improving soil structure and providing key plant nutrients, especially N, P, and $\mathrm{K}^{[13]}$. In addition, the application of vermicompost significantly increased marketable yield, important nutrient metabolites, and antioxidant capacity of Chinese cabbage ${ }^{[14]}$. A further advantage of organic fertilizers is no residues in the crops so that they are safe for human health ${ }^{[15]}$.

The products of vermicomposting systems are liquid organic fertilizer and vermicompost. Liquid organic fertilizer is more easily absorbed by plants by spraying, usually onto the leaves; it can also be applied onto the soil around the plants ${ }^{[16]}$. The growth of earthworms is very dependent on the type of feed that they receive, and their growth will be increased if the feed contains a lot of organic matter ${ }^{[17]}$. The weight of earthworms is strongly influenced by media conditions and the availability of nutrients ${ }^{[18]}$. The type of feed given to the worms will determine the amount and quality of fertilizer that is produced ${ }^{[19]}$. Reduced availability of nutrients in the media will cause decreased metabolic activity, resulting in decreased metabolic energy ${ }^{[20]}$ and both the amount and quality of the feed. In general, suitable feedstuffs can comprise a wide range of organic wastes, such as vegetable waste, sawdust or residual mushroom media, forage waste, livestock manure, the midribs, leaves, stalks and humps of banana palms, rice straw waste and tofu pulp ${ }^{[21]}$.

Given the potential role that vermicomposting could play in zero burn agriculture on peatlands in Indonesia, the objective of this study was to examine the effect of different earthworm types and types of feed on the quality of liquid organic fertilizer and compost produced from a vermicomposting system established in a representative farm setting in Central Kalimantan, Indonesia.

\section{Method}

This research was conducted at the Experimental Site of the Department of Agriculture, Faculty of Agriculture, Palangka Raya University, Indonesia, while laboratory analysis was carried out at the Analytical Laboratory, University of Palangka Raya. The study used a factorial completely randomized design (CRD) which consisted of two treatment factors. The first factor was the type of worm, namely Red Earthworn (Lumbricus rubellus) and African Night Crawler (Eudrilus eugeniae). The second factor was the type of worm feed which consisted of three types: No feed/control $(\mathrm{NF})$, green vegetable waste (GVW) and waste feed resulting from zero burning land preparation system (ZBW). The ZBW material comprised land clearance waste obtained from three (replicate) peatland areas dominated by the trees Tumih (Combretocarpus rotundatus) and Geronggang (Cratoxylon arborescens BI).
Research on the quality of the vermicomposting products, both liquid fertilizer and vermicompost, was carried out through laboratory analysis to assess the macronutrient content.

The procedure of the research was as follows. Worm growing media made from around $30 \mathrm{~kg}$ of cow dung with added water (volume ratio of 2: 1) was prepared by stirring and allowed to stand for one week to soften the media. The worm media was placed in the upper basin of a vermicomposting container. The basin had gauze at the bottom and the media was added to a thickness of about $5 \mathrm{~cm}$ (weight of about $1.5 \mathrm{~kg}$ ) on top of this gauze. Worm feedstuffs obtained from either green vegetable waste or zero burning waste were refined using a chopper. Each of these ingredients was soaked in water for three days with a ratio of 1:2 water to feed ingredients. After soaking, the feed ingredients were drained and ready for use. To construct a vermiculture container, two plastic boxes measuring $26 \mathrm{~cm} \times$ $19 \mathrm{~cm} \times 9 \mathrm{~cm}$ were used. The first box served as a bottom box to receive the worm liquid and a second box served as an upper box to hold the worm media. For the upper box, a sufficient amount of holes was made in the base so that the liquid worm fertilizer could drip down into the bottom box. The surface of the upper box was covered with gauze so that the worms could not descend into the bottom box. Bamboo sticks were placed on each side as support for the boxes.

The media in the boxes was seeded by adding worms (weight $50 \mathrm{~g}$ per box) evenly over the media surface. Each box was then covered with a tarpaulin and then tied with a rope. The box was kept in a cool place, avoid exposure to sunlight, ants, rats, and other pests. Routine reversal of the media and watering with $250 \mathrm{~mL}$ of water evenly across the surface were carried out once a week to ensure aeration and moisture levels of the media. Worm feed was provided once a week in the form of food that had been cut into small pieces and soaked with water for three days. The feed was applied by spreading evenly over the media. Harvesting of liquid worm organic fertilizer and vermicompost was carried out after 35 days of the composting process. Samples of the liquid organic fertilizer and vermicompost were then analyzed in the laboratory for the following parameters:

1) The quality of liquid fertilizer was determined by analyzing for $\mathrm{NH}_{3}$ (titration), $\mathrm{NO}_{3}, \mathrm{NO}_{2}$ and Total-P (spectrophotometry), and $\mathrm{K}$ (AAS); to determine the quality of the vermicompost, $\mathrm{N}$ (Kjedhal), P (Bray I), and Bases Cation $\left(\mathrm{N} \mathrm{HH}_{4} \mathrm{OAc} \mathrm{pH} 7\right)$ were analyzed.

2) The temperature and $\mathrm{pH}$ value of the vermicompost were measured using a $\mathrm{pH}$ meter.

3 ) In addition, the weight of the earthworm colony harvested at the end of the composting period ( $35 \mathrm{~d}$ ) was obtained. Worms were separated from the media and weighed to determine the change in weight of the colony after composting.

The data obtained were analyzed by analysis of variance (ANOVA) using the F test level $\alpha=5 \%$. If the differences were considered significant, the honestly significant difference test at the level of $\alpha=5 \%$ was followed to determine the difference between treatments.

\section{Results and discussion}

\subsection{Quality of liquid fertilizer}

The results of the analysis of variance for the effect of worm type and feed type on the quality of liquid fertilizer from vermicomposting are presented in Figures 1 and 2 . These results indicated that the type of feed has a significant effect on the $\mathrm{pH}$ 
value of the liquid fertilizer, with feed derived from green vegetable waste provided the highest $\mathrm{pH}$ value at an average of 8.17. In contrast, the type of worm does not significantly affect the $\mathrm{pH}$ value of the liquid fertilizer. All of the liquid organic fertilizers produced in the study have a $\mathrm{pH}$ value above neutral, which is beneficial for agriculture in acidic peat soils (typically around $\mathrm{pH} 4$ ). These results are in line with those obtained by the previous researcher ${ }^{[22]}$ who observed average value of $\mathrm{pH} 8$ of liquid fertilizer produced in the process of worm composting but differ from those obtained in some other studies, e.g., $\mathrm{pH} 5.2^{[23]}$ and $\mathrm{pH} 6.28^{[24]}$. The $\mathrm{pH}$ level needed by plants for good growth is around neutral ( $\mathrm{pH} 7)$, at which level there is maximum availability of nutrients in the growing medium. During the worm composting process, organic acids are neutralized and the compost will usually mature at a $\mathrm{pH}$ range between 6 and $8^{[25]}$.

For $\mathrm{N}$ and $\mathrm{P}$ nutrient content in the liquid fertilizer, the treatment effects are not significantly different. The content of $\mathrm{NH}_{3}, \mathrm{NO}_{2}, \mathrm{NO}_{3}$ and Total-N ranged between $0-0.50 \mathrm{mg} / \mathrm{L}$; 0.78-2.76 $\mathrm{mg} / \mathrm{L} ; \quad 2.15-10.25 \mathrm{mg} / \mathrm{L}$, and $3.77-11.91 \mathrm{mg} / \mathrm{L}$, respectively (Figures $2 \mathrm{a}-2 \mathrm{~d}$ ), while the $\mathrm{P}$ content ranged from $2.65-4.53 \mathrm{mg} / \mathrm{L}$ (Figure 2e). Green vegetable waste feed provided higher values for $\mathrm{pH}$ value, $\mathrm{NH}_{3}, \mathrm{NO}_{2}$ and Total-K, while the Lumbricus rubellus worm type provided higher $\mathrm{pH}$ value and content of $\mathrm{NO}_{2}, \mathrm{NO}_{3}$, Total-N and Total-K. The combination treatment between worm species and feed type together

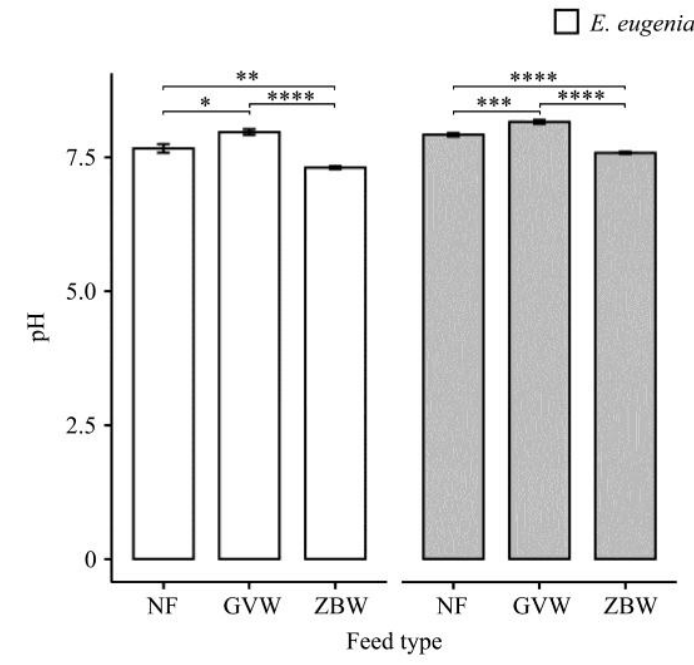

a.

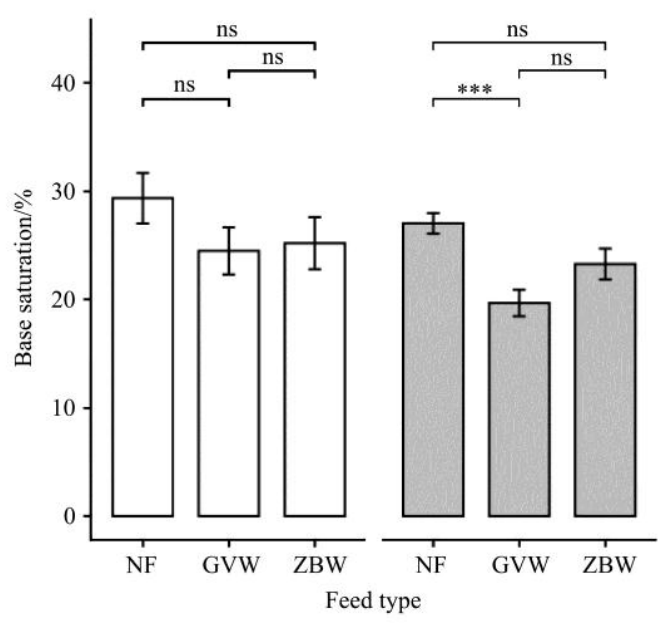

c. significantly affected the total $\mathrm{K}$ content of the liquid fertilizer (Figure 2f), with the $\mathrm{K}$ content ranging between 1084.41$2811.41 \mathrm{mg} / \mathrm{L}$. The results obtained from this vermicomposting process had lower $\mathrm{N}, \mathrm{P}$ and $\mathrm{K}$ content of the liquid organic fertilizer than those obtained by previous research ${ }^{[26]}$, whose values for $\mathrm{N}, \mathrm{P}$ and $\mathrm{K}$ content ranged from $1.08 \%-1.34 \%$; $0.22 \%-0.59 \%$; and $0.11 \%-0.17 \%$, respectively. The nutrient content is very likely to be dependent on the $\mathrm{C} / \mathrm{N}$ ratio of the raw material.

\subsection{Quality of vermicompost}

The results of the analysis of variance for the effect of worm type and feed type on the quality of vermicompost are presented in Figures $1 \mathrm{~b}-1 \mathrm{~d}$ and Figure 3. These results indicated that the combinations of types of earthworm and feed significantly affect the $\mathrm{pH}$ value of the vermicompost (Figure $1 \mathrm{~b}$ ). The $\mathrm{pH}$ value of compost produced from all treatments is above neutral with values between 7.25 and 8.73. The combination of vegetable waste and the worm Eudrilus eugeniae produced the highest vermicompost $\mathrm{pH}$ value. Previous studies have shown that the $\mathrm{pH}$ value of worm compost is above neutral ${ }^{[27]}$, and the $\mathrm{pH}$ value dropped slightly at the beginning of the composting process due to the organic acids produced from bacterial activity ${ }^{[28]}$. The $\mathrm{pH}$ value of the vermicompost may depend on the type of raw material used in the feed ${ }^{[29]}$. Previous studies of vermicomposts produced from cattle manure have noted $\mathrm{pH}$ values of $6.0^{[30]}$ or $6.7^{[29]}$, whereas the $\mathrm{pH}$ of this cow manure vermicompost was 7.58.

L. rubellus

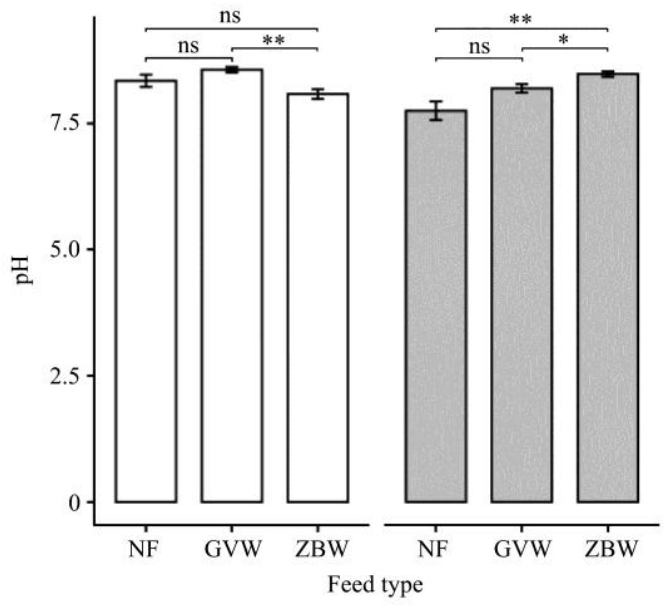

b.

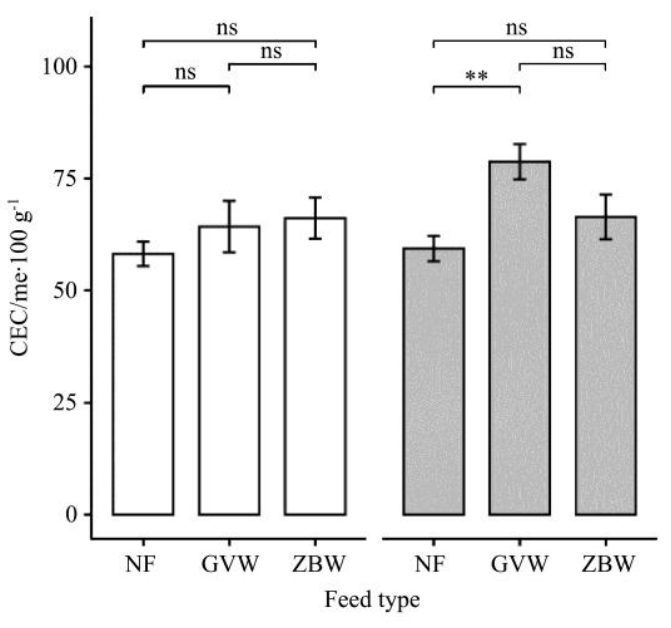

d.

Figure 1 Analysis of variance of the effect of worms and feed on the (a) $\mathrm{pH}$ value of liquid fertilizer and (b) $\mathrm{pH}$ value of vermicompost, (c) base saturation and (d) CEC of vermicompost 

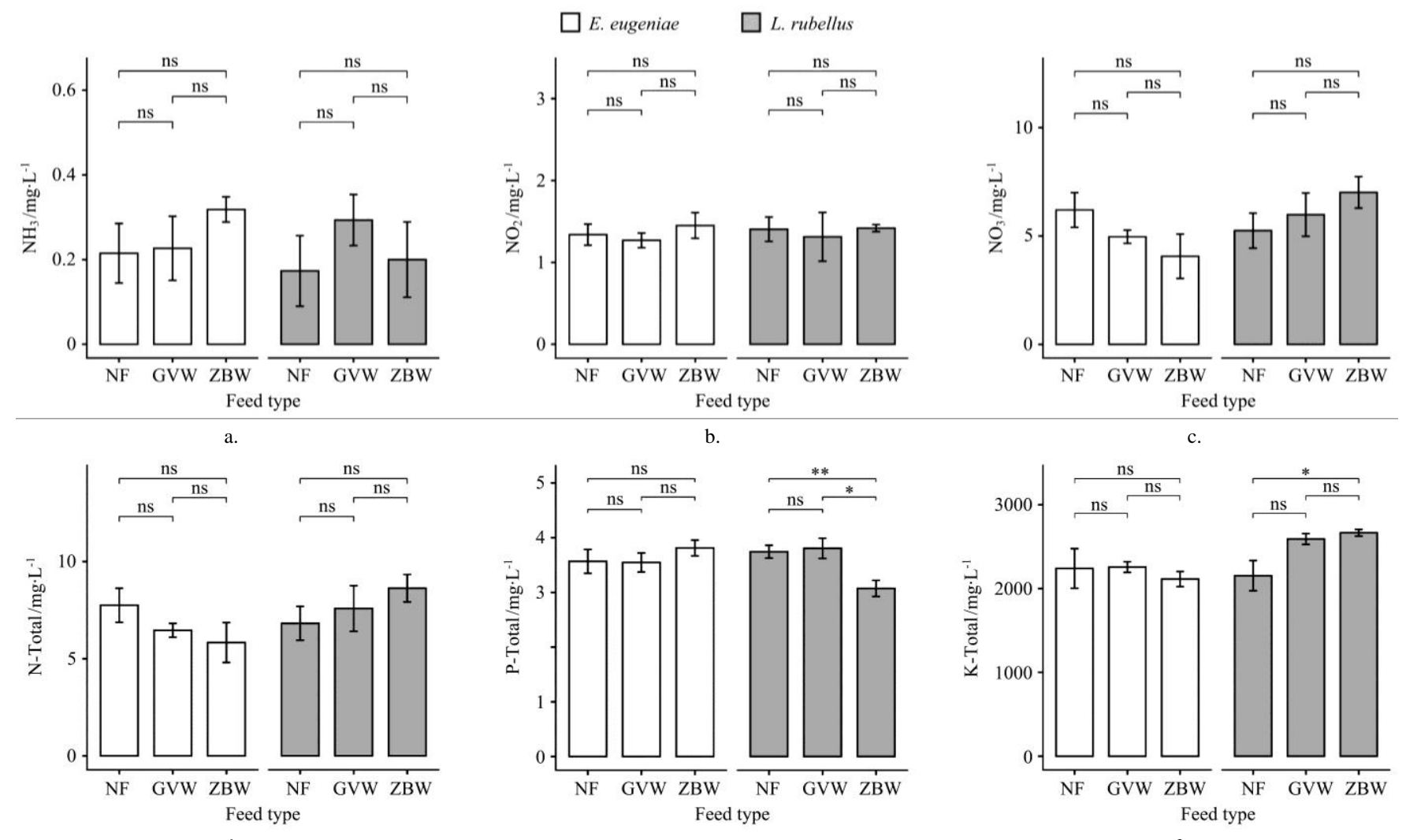

Figure 2 Analysis of variance of the effect of worms and feed on $\mathrm{NH}_{3}, \mathrm{NO}_{2}, \mathrm{NO}_{3}$, Total-N, total-P and total-K content of liquid fertilizer
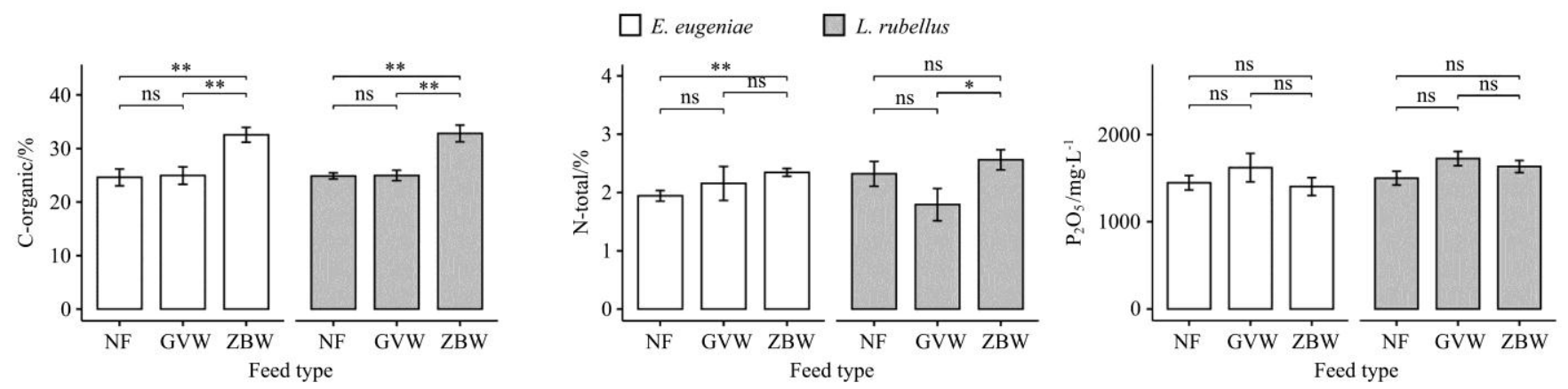

a.

b.
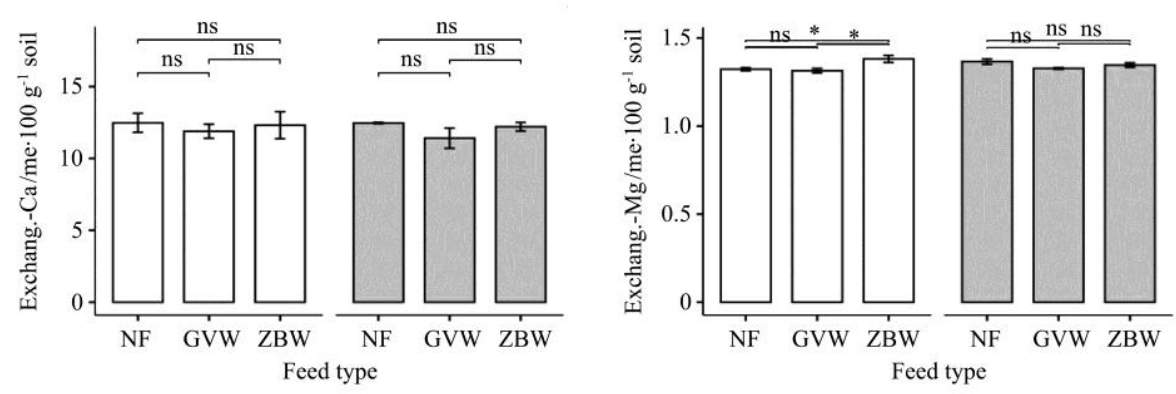

d.

e.

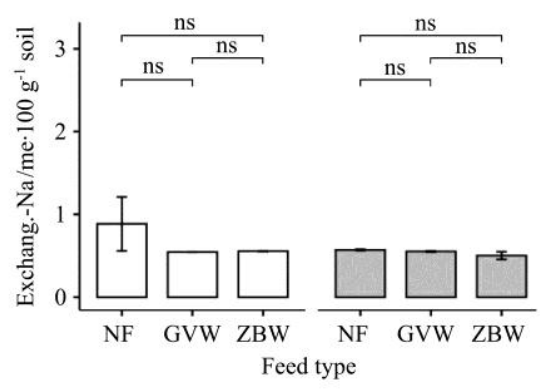

f.

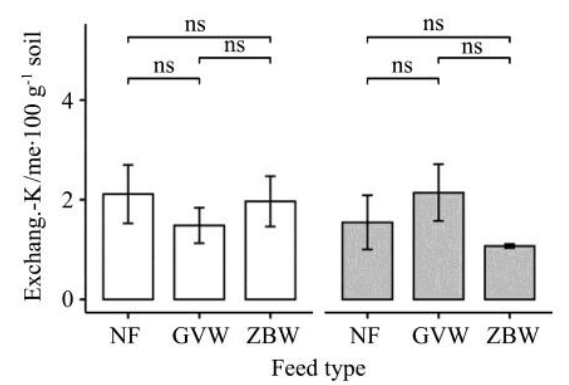

g.

Figure 3 Analysis of variance of the effect of worms and feed on C-organic, Total- $\mathrm{N}, \mathrm{P}_{2} \mathrm{O}_{5}$, exchangeable cations of vermicompost 
From Figures 3a-3c, 1c and 1d, it appears that the treatment of the feed originating from the zero burning waste resulted in vermicompost that significantly different from the other two feeds in terms of the C-organic content, but overall neither worm nor feed type has a significant effect on N, P and K content, Base Saturation or CEC. The combinations of types of worm treatment and types of feed do not have a significant effect on the content of exchangeable-Ca, $\mathrm{Mg}, \mathrm{Na}$ and $\mathrm{K}$ (Figures 3d-3g). A single combination of green vegetable waste plus Lumbricus rubellus yield the highest effect on soil CEC, but for Base Saturation, the combination of no-feed and Eudrilus eugeniae showed a higher value. The CEC range of the vermicompost was 51.11$93.36 \mathrm{me} / 100 \mathrm{~g}$ of soil; Base Saturation range was $15.75 \%-37.44 \%$; the C-organic content range was $19.68 \%-38.14 \%$; Total-N range was $0.95 \%-3.31 \%$ and $\mathrm{P}_{2} \mathrm{O}_{5}$ range was $1221.71-2344.04 \mathrm{ppm}$. The animal manure was decomposed during the production of vermicompost, and its physical and chemical properties were changed with the degradable organic $\mathrm{C}$ being oxidized and stabilized $^{[31]}$.

Of the three feed materials, the highest C-organic content was found in the vermicompost produced from the zero burning waste. This is likely because this feed material is quite diverse, comprising stems, branches, and leaves, with high C-organic and high lignin content in the fresh material. Despite this high content of woody material, results from this study demonstrated that the zero burning waste still has the potential to be a suitable feedstuff for earthworms. In addition, there were similar values for the $\mathrm{N}, \mathrm{P}$ and $\mathrm{K}$ content of the vermicompost, whether it was derived from vegetable feed or zero burning waste. The vermicomposting process is a result of the combined action of the earthworms and the microflora living in earthworm intestines and the growth medium $^{[32]}$. Earthworms accelerated composting by bioturbation and aeration, provided a final product that is less rich in nitrogen and organic matter but enhanced with available plant nutrients. In addition to supplying nutrients, adding vermicompost to soil also increased the soil organic matter (OM) content which can be an added benefit for farmers wishing to maintain soil fertility ${ }^{[33]}$. On the basis of these results, the zero burning waste material can be considered as a suitable feedstuff for vermiculture, with the resultant vermicompost likely to be a suitable soil ameliorant for use on low fertility peat soils.

For the effect of worm and feed type on the exchangeable-Ca, $\mathrm{Mg}, \mathrm{Na}$ and $\mathrm{K}$ in the vermicompost (Figures 3d-3g), it appears that the combination of these two factors had an effect on exchangeable-Mg, while the other three parameters were not significantly different. Zero burning waste and Eudrilus eugeniae worms gave a better content of exchangeable-Ca and $\mathrm{Mg}$, while the combination of no-feeding and Eudrilus eugeniae worms had a better effect on exchangeable-Na and $\mathrm{K}$. The content of exchangeable-Ca in the vermicompost ranged between 8.44$16.05 \mathrm{me} / 100 \mathrm{~g}$ soil, exchangeable-Mg ranged between 1.28$1.44 \mathrm{me} / 100 \mathrm{~g}$ soil, exchangeable-Na ranged between 0.27$2.51 \mathrm{me} / 100 \mathrm{~g}$ soil and exchangeable-K ranged from 1.47$2.86 \mathrm{me} / 100 \mathrm{~g}$ soil.

In terms of the quality of vermicompost produced from zero burning waste compared to other feedstuffs, it appears that it is not significantly different from the other feeds, especially the green vegetable waste, again showing the potential of this material for use in worm cultivation.

\subsection{Weight of worm colonies}

The results presented in Figure 4 show that neither worm type not type of feed affects the weight (biomass) of the worm colonies, but the addition of feed (compared to no feed) does increase the weight of worms, with the highest weight resulting from the use of the zero burning waste feed. The combination of zero burning waste and with Lumbricus rubellus gave the highest average colony weight. The weight of the worm colony at the end of the experiment ranged between 61.20-107.4 g, compared to a starting weight of $50 \mathrm{~g}$.
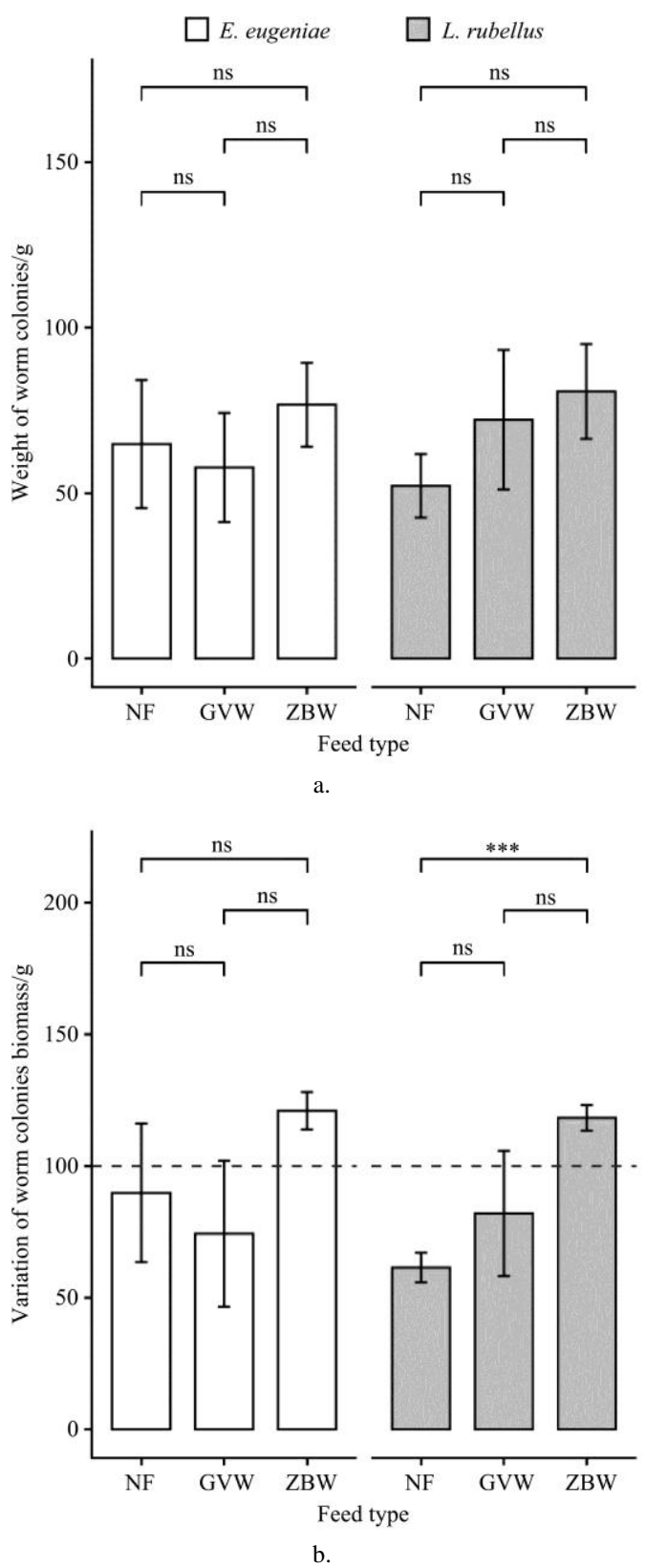

Figure 4 Analysis of variance of the effect of worms and feed on the weight of worm colonies $(\mathrm{g})$

The increase in the weight of earthworms in this study indicated that the nutritional content of the media, especially the zero burning waste, can meet the nutritional requirements of Lumbricus rubellus and Eudrilus eugeniae earthworms. During the composting process, microorganisms degraded the component ingredients of the organic matter such as carbohydrates, proteins and fats, and convert them into simpler forms such as glucose, amino acids, and fatty acids ${ }^{[4]}$. Organic material in this simple form can be easily digested and absorbed by earthworms and used effectively for the formation of new body tissues, as indicated by an increase in the body weight of the earthworms in this study. 
These results provided further confirmation that zero burning waste media can be used as an alternative food for worm cultivation.

\section{Conclusions and recommendations}

1) The type of feed had a significant effect on the $\mathrm{pH}$ value of the liquid fertilizer produced from the vermiculture; feed from green vegetable waste gave the highest $\mathrm{pH}$ value while worm type had no significant effect on $\mathrm{pH}$ value.

2) The type of worms and the type of feed have no significant effect on the $\mathrm{N}$ and $\mathrm{P}$ content of the liquid fertilizer. A feed of green vegetable waste compared to other feedstuffs produced higher values for $\mathrm{pH}$ value, $\mathrm{NH}_{3}, \mathrm{NO}_{2}$ and Total-K, while Lumbricus rubellus worms produced higher values for $\mathrm{pH}, \mathrm{NO}_{2}$, $\mathrm{NO}_{3}$, Total-N and Total-K content compared with Eudrilus eugeniae worms. The combination treatment between the type of worm and the type of feed together had a significant effect on the total $\mathrm{K}$ content of the liquid fertilizer.

3) The combination of the type of earthworms and type of feed significantly affected the $\mathrm{pH}$ value of the vermicompost. The combination of green vegetable waste and Eudrilus eugeniae worm produced the highest vermicompost $\mathrm{pH}$ value. The treatment with the feed derived from zero burning waste was significantly different from the other two feeds in terms of producing vermicompost with a higher C-organic content, but neither worm nor feed type had a significant effect on the content of N, P and K, Base Saturation and CEC. The combination of the two types of worm treatment and the type of feed had a significant effect on the content of exchangeable-Ca, but not on exchangeable-Mg, $\mathrm{Na}$ and K. The combination of green vegetable waste and Lumbricus rubellus worm gave the highest soil CEC, but for Base Saturation, no-feeding with Eudrilus eugeniae produced a higher value.

4) The type of worm and type of feed significantly affected the exchangeable-Mg content in the vermicompost, while the other three parameters were not significantly different. The combination of zero burning waste and Eudrilus eugeniae worms gave a better content of exchangeable $\mathrm{Ca}$ and $\mathrm{Mg}$, while no-feeding and Eudrilus eugeniae worms provided higher values for exchangeable $\mathrm{Na}$ and $\mathrm{K}$.

5) Type of worm and type of feed did not significantly affect the weight of the worm colonies, but the addition of feed increased the weight of the worms with the highest weight resulting from the use of zero burning feed. This waste in combination with the Lumbricus rubellus worm gave the highest average weight of the worm colony at the end of the experiment.

6) The results of this study indicated that the wastes generated from zero burning land clearing practices in Central Kalimantan can be used as a feedstuff for vermiculture and the resulting liquid fertilizer and vermicompost are suitable for agricultural use. Vermiculture could, therefore, play a role in supporting the livelihoods of farmers who can no longer use fire to dispose of land clearance debris and crop residues, while also provided a suitable soil ameliorant for improving crop growth.

\section{Acknowledgements}

The authors acknowledge the Research and Community Service Institute at the University of Palangka Raya for providing financial support for conducting this research, and the students of the Agronomy Department who helped a lot and were involved in this research for their studies, especially grateful to Professor Susan E. Page of the University of Leicester, UK, for her input and correction on this paper and to Dr. Jonay Jovani Sancho of the University of Nottingham, UK, for his help on statistical analysis.

\section{[References]}

[1] Page S E, Rieley J O, Banks C J. Global and regional importance of the tropical peatland carbon pool. Global Change Biol., 2011; 17(2): 798818.

[2] Sinha R K. Earthworms vermicompost, a powerful crop nutrient over the conventional compost and protective soil conditioner against the destructive chemical fertilizers for food safety and security Am-Euras. J. Agric. \& Environ. Sci., 2009; 5: 1-55.

[3] Pangkulun R. Earthworm cultivation business of Lumbricus rubellus (Indonesian). Penebar Swadaya, Jakarta, 2010.

[4] Munroe G. Manual of on-farm vermicomposting and vermiculture Organic Agriculture Centre of Canada, Canada, 2003.

[5] Sathianarayanan A, Khan B. An eco-biological approach for resource recycling and pathogen (Rhizoctoniae solani Kuhn.) Suppression. J. of Enviromental Protection Science, 2008; 2: 36-39.

[6] Andhikari N P, Mishra B N. Effect of integrated sources of nitrogen on yield of aromatic rice and their residual effect on succeeding. In Extended Summaries: 2nd International Agronomy Congress, held at New Delhi, India from November 26-30, 2002; pp.63-64.

[7] Behera U K, Sharma A R, Pandey H N. Sustaining productivity of wheat-soybean cropping system through integrated nutrient management practices on the Vertisols of central India Plant Soil, 2007; 97: 185-199.

[8] Winten K T I. Effects of cassava and nitrogen fertilizer dose on growth and yield of lettuce (Lactuca sativa L). Thesis. Program Pascasarjana Universitas Udayana Denpasar, 2006. (in Indonesian)

[9] Srilaba N. Effects of vermicompost doses and phosphate fertilizer doses on sweet corn (Zea mays.Saccharata Strut) production in Andisol Candikuning. Thesis. Denpasar Universitas Udayana, 2013. (in Indonesian)

[10] Liu M, Hu F, Chen X, Huang Q, Jiao J, Zhang B, Li H. Organic amendments with reduced chemical fertilizer promote soil microbial development and nutrient availability in a subtropical paddy field: the influence of quantity, type and application time of organic amendments. Appl. Soil Ecol., 2009; 42: 166-175.

[11] Singh K P, Snman A, Singh P N, Srivastava T K. Improving quality of sugarcane-growing soils by organic amendments under subtropical climatic conditions of India. Biol Fertil Soils, 2007; 44: 367-376.

[12] Padel S, Röcklinsberg H, Schmid O. The implementation of organic principles and values in the European regulation for organic food. Food Policy, 2009; 34: 245-251.

[13] Lingga P, Marsono, Manual for fertilizers applications. Pupuk, Penebar Swadaya, Jakarta, 2000. (in Indonesian)

[14] Wang D H, Shi Q H, Wang X F, Wei M, Hu J Y, Liu J, et al. Influence of cow manure vermicompost on the growth, metabolite contents, and antioxidant activities of Chinese cabbage (Brassica campestris ssp. chinensis). Biol Fertil Soils, 2010; 46: 689-696.

[15] Musnamar E I. Liquid and solid organic fertilizers, production and application. Penebar Swadaya, Jakarta, 2007. (in Indonesian)

[16] Djuarnani N, Kristian, Setiawan B D. Quick ways to produce compost Cetakan Pertama. Agromedia Pusaka, Jakarta, 2005. (in Indonesian)

[17] Suin N M. Soil animal ecology. Bumi Aksara, Jakarta, 1997. (in Indonesian)

[18] Pangkulun R. Success of earthworms cultivation of Lumbricus rubellus. Penebar Swadaya, Jakarta, 1999. (in Indonesian)

[19] Hartati S B. Application of bokashi fertilizer and azolla microphylla based liquid organic fertilizer in pakcoy plants (Brassica chinensis L.). Pascasarjana, Universitas Jendral Sudirman, Purwokerto, 2012. (in Indonesian)

[20] Wulandari D. Growth and breeding of eisenia foetida savigny's earthworm in the cow manure media containing mushroom waste (Indonesian). Undergraduate thesis. Jurusan Biologi, FMIPA, IPB, Bogor, 2000.

[21] Rozaq A, Novianto G. Utilization of water hyacinth plants as liquid fertilizer. Undergraduate thesis. Skripsi. Jurusan Teknik Kimia Fakultas Teknologi Industri, Universitas Pembangunan Nasional "Veteran", Jawa Timur, 2010. (in Indonesian)

[22] Mulahartani R. Effects of feed type on the quality of liquid organic fertilizer compost of Lumbricus rubellus. Undergraduate thesis. Jurusan Budidaya Pertanian, Fakultas Pertanian, Universitas Palangka Raya, 2017. (in Indonesian)

[23] Arifah S M. Food composition analysis of Lumbricus sp. on the quality 
of vermicompost and its application in mustard plants. Jurnal Gamma, 2014; 9(2): 63-72. (in Indonesian)

[24] Dwiyantono, R., Sutaryo and Purnomoadi, A. Comparison of the quality of vermicompost produced from cattle feces and buffalo feces. Animal Agriculture Journal, 2014; 3(2): 147-154. (in Indonesian)

[25] Nurdini L, Amanah R D, Utami A U. Processing of cabbage waste into compost using Takakura method. Prosiding Seminar Nasional Teknik Kimia, Yogyakarta, 2016; ISSN 1693-4393. (in Indonesian)

[26] Imanudin O, Kurnani T B A, Wahyuni S. Effects of $\mathrm{C} / \mathrm{N}$ ratio mix of duck feces and sawdust (Albizzia falcata) on the quality of liquid organic fertilizer, vermicompost and earthworm biomass. Available: http://repository.unpad.ac.id/22130/1/Journal-Tesis-.pdf. 2016. (in Indonesian)

[27] Sucipta N K S P, Kartini N L, Soniari N N. Effect of Earthworm Populations and Media Types on the Quality of Organic Fertilizers. E-Jurnal Agroekoteknologi Tropika, 2015; 4(3): 213-223.

[28] Sutanto. Determinants factor of compost quality. Available: http://www.vedcmalang.com/pppptkboemlg/index.php/artikel-coba-2/plh/5
65 peduli-kesehatan-ii. 2002. (in Indonesian) Accessed on [2014-06-16]

[29] Alves M R, Landgraf M D, Resende M O O. Absorption and desorption of herbicide alaclor on humic acid fractions obtained from two vermicompost. J Environ Sci Health, 2001; 36: 797-808

[30] Jordao C P, Pereira M G, Einloft R, Santana M B, Bellato C R, Vargas de Mello J W. Removal of $\mathrm{Cu}, \mathrm{Cr}, \mathrm{Ni}, \mathrm{Zn}$ and $\mathrm{Cd}$ from electroplating wastes and synthetic solutions by vermicompost of cattle manure. J Environ Sci Health, 2002; 37: 875-892.

[31] Albanell E, Plaixats J, Cabrero T. Chemical changes during vermicomposting (Eisenia fetida) of sheep manure mixed with cotton industrial wastes. Biol Fertil Soils, 1988; 6: 266-269.

[32] Grapelli A, Tomati U, Galli E. Vermicomposting of combined sewage sludge and municipal refuse. Proc. Int. Symp. on Agricultural and Environmental Prospects in Earthworm Farming, Rome, Italy, 1983; pp.73-80.

[33] Paradelo R, Cendón Y, Moldes A B, Barral M T. A pot experiment with mixtures of slate processing fines and compost. Geoderma, 2007; 141: 363-369. 